\title{
User's Guide for the Delaware River Basin Streamflow Estimator Tool (DRB-SET)
}

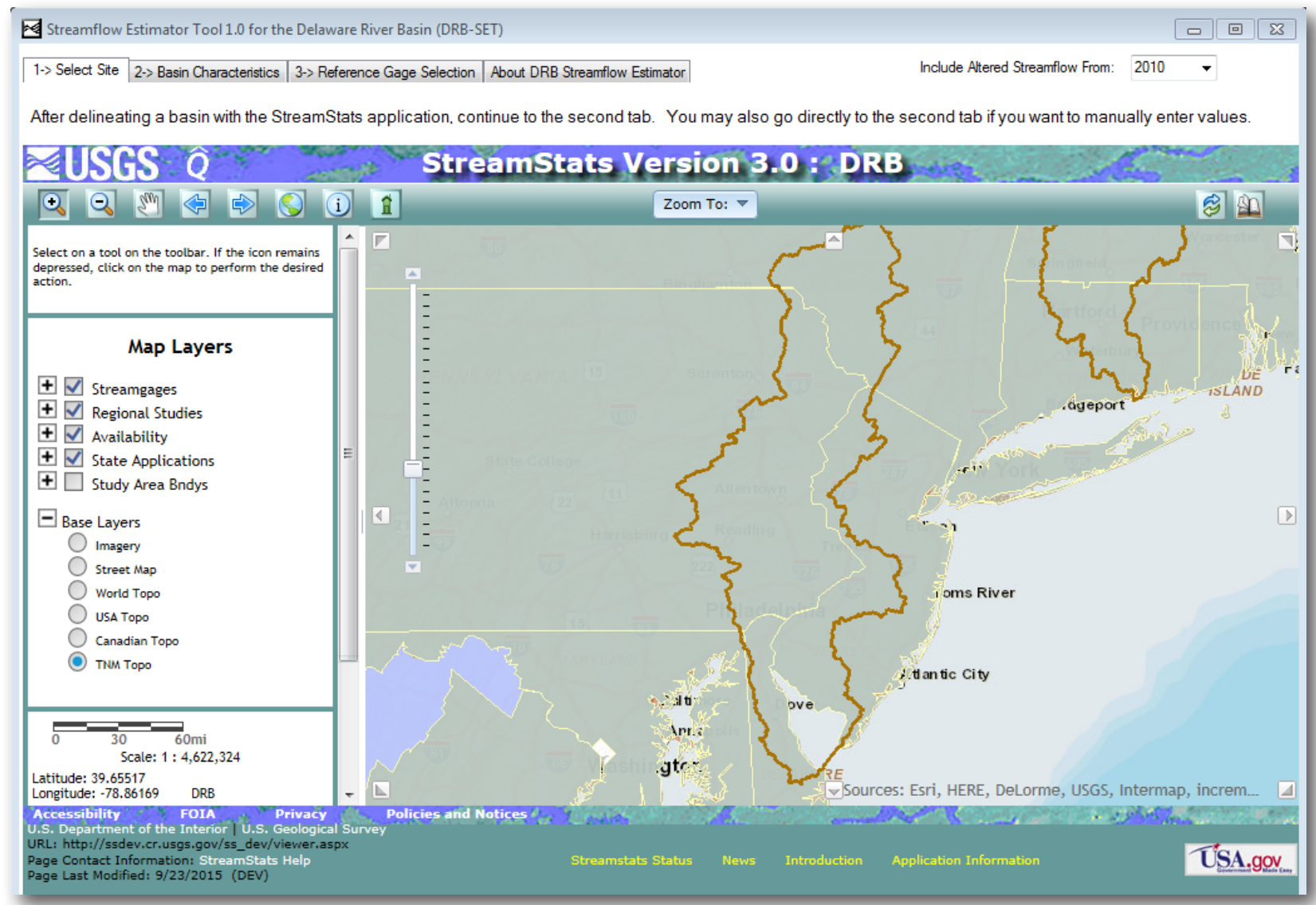

Open-File Report 2015-1192

U.S. Department of the Interior

U.S. Geological Survey 
Cover. Screen capture of the opening screen of DRB-SET. 


\section{User's Guide for the Delaware River Basin Streamflow Estimator Tool (DRB-SET)}

By Marla H. Stuckey and James E. Ulrich

Open-File Report 2015-1192 


\title{
U.S. Department of the Interior SALLY JEWELL, Secretary
}

\section{U.S. Geological Survey Suzette M. Kimball, Director}

\author{
U.S. Geological Survey, Reston, Virginia: 2016
}

For more information on the USGS - the Federal source for science about the Earth, its natural and living resources, natural hazards, and the environment—visit http://www.usgs.gov or call 1-888-ASK-USGS.

For an overview of USGS information products, including maps, imagery, and publications, visit http://www.usgs.gov/pubprod/.

Any use of trade, firm, or product names is for descriptive purposes only and does not imply endorsement by the U.S. Government.

Although this information product, for the most part, is in the public domain, it also may contain copyrighted materials as noted in the text. Permission to reproduce copyrighted items must be secured from the copyright owner.

Suggested citation:

Stuckey, M.H., and Ulrich, J.E., 2016, User's Guide for the Delaware River Basin Streamflow Estimator Tool (DRB-SET): U.S. Geological Survey Open-File Report 2015-1192, 6 p., http://dx.doi.org/10.3133/ofr20151192. 


\section{Contents}

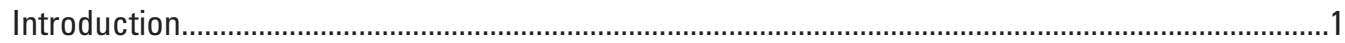

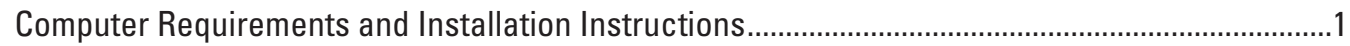

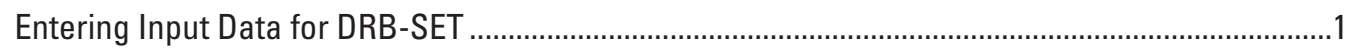

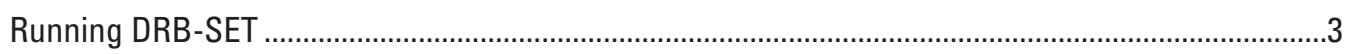

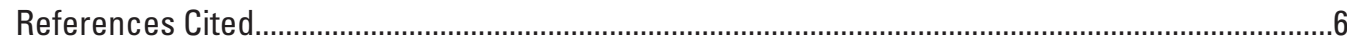

\section{Figures}

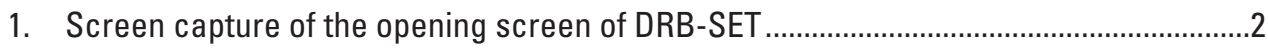

2. Screen capture of basin characteristics table in DRB-SET ...............................................

3. Screen capture of Reference Gage Selection tab in DRB-SET .......................................

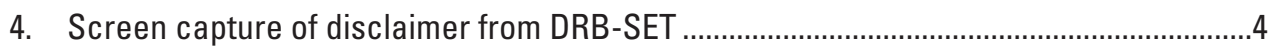

5. Screen capture of Report worksheet from DRB-SET .........................................................

6. Screen capture of WaterUse worksheet from DRB-SET ...................................................6 


\section{Conversion Factors}

\begin{tabular}{|c|c|c|}
\hline Multiply & By & To obtain \\
\hline \multicolumn{3}{|c|}{ Length } \\
\hline inch (in.) & 2.54 & centimeter $(\mathrm{cm})$ \\
\hline foot $(\mathrm{ft})$ & 0.3048 & meter $(\mathrm{m})$ \\
\hline mile (mi) & 1.609 & kilometer (km) \\
\hline \multicolumn{3}{|c|}{ Area } \\
\hline acre & 4,047 & square meter $\left(\mathrm{m}^{2}\right)$ \\
\hline square mile $\left(\mathrm{mi}^{2}\right)$ & 259.0 & hectare (ha) \\
\hline square mile $\left(\mathrm{mi}^{2}\right)$ & 2.590 & square kilometer $\left(\mathrm{km}^{2}\right)$ \\
\hline \multicolumn{3}{|c|}{ Flow rate } \\
\hline cubic foot per second $\left(\mathrm{ft}^{3} / \mathrm{s}\right)$ & 0.02832 & cubic meter per second $\left(\mathrm{m}^{3} / \mathrm{s}\right)$ \\
\hline $\begin{array}{l}\text { cubic foot per second per square mile } \\
{\left[\left(\mathrm{ft}^{3} / \mathrm{s}\right) / \mathrm{mi}^{2}\right]}\end{array}$ & 0.01093 & $\begin{array}{l}\text { cubic meter per second per square } \\
\text { kilometer }\left[\left(\mathrm{m}^{3} / \mathrm{s}\right) / \mathrm{km}^{2}\right]\end{array}$ \\
\hline cubic foot per day $\left(\mathrm{ft}^{3} / \mathrm{d}\right)$ & 0.02832 & cubic meter per second $\left(\mathrm{m}^{3} / \mathrm{s}\right)$ \\
\hline gallon per day (gal/d) & 0.003785 & cubic meter per day $\left(\mathrm{m}^{3} / \mathrm{d}\right)$ \\
\hline gallon per day per square mile $\left[(\mathrm{gal} / \mathrm{d}) / \mathrm{mi}^{2}\right]$ & 1,233 & cubic meter $\left(\mathrm{m}^{3}\right)$ \\
\hline million gallons per day $(\mathrm{Mgal} / \mathrm{d})$ & 0.001233 & cubic hectometer $\left(\mathrm{hm}^{3}\right)$ \\
\hline inch per hour (in/h) & 0.0254 & meter per hour $(\mathrm{m} / \mathrm{h})$ \\
\hline inch per year (in/yr) & 25.4 & millimeter per year (mm/yr) \\
\hline \multicolumn{3}{|c|}{ Hydraulic conductivity } \\
\hline foot per day (ft/d) & 0.3048 & meter per day $(\mathrm{m} / \mathrm{d})$ \\
\hline
\end{tabular}

Temperature in degrees Fahrenheit $\left({ }^{\circ} \mathrm{F}\right)$ may be converted to degrees Celsius $\left({ }^{\circ} \mathrm{C}\right)$ as follows:

${ }^{\circ} \mathrm{C}=\left({ }^{\circ} \mathrm{F}-32\right) / 1.8$

Vertical coordinate information is referenced to North American Vertical Datum of 1988 (NAVD 88).

Horizontal coordinate information is referenced to North American Datum of 1983 (NAD 83). 


\title{
User's Guide for the Delaware River Basin Streamflow Estimator Tool (DRB-SET)
}

\author{
By Marla H. Stuckey and James E. Ulrich
}

\section{Introduction}

The Delaware River Basin Streamflow Estimator Tool (DRB-SET, v. 1.0) is a tool for the simulation of streamflow at a daily time step for an ungaged stream location in the Delaware River Basin for water years ${ }^{1}$ 1960-2010. DRB-SET was developed by the U.S. Geological Survey (USGS) and funded through WaterSMART as part of the National Water Census, a USGS research program on national water availability and use that develops new water accounting tools and assesses water availability at regional and national scales. DRB-SET uses a QPPQ approach (Fennessey, 1994; Archfield and others, 2010; Stuckey and others, 2014), which relates probability exceedances at a gaged location to those at an ungaged stream location. Once the ungaged stream location has been identified by the user, an appropriate streamgage is automatically selected in DRB-SET using streamflow correlation (map correlation method). Alternately, the user can manually select a streamgage or use the closest streamgage. The streamgage selected, termed the "reference" streamgage, in addition to having a strong correlation with streamflow in the ungaged subbasin, needs to be representative of the ungaged basin with similar hydrologic and basin characteristics and have streamflow that is minimally altered by human activities. A report file is generated documenting the reference streamgage and ungaged stream location information, basin characteristics, any warnings, baseline (minimally altered) and altered (affected by regulation, diversion, mining, or other anthropogenic activities) daily mean streamflow, and the mean and median streamflow. The estimated daily flows for the ungaged stream location can be easily exported as a text file that can be used as input into a statistical software package to determine additional streamflow statistics, such as flow duration exceedance or streamflow frequency statistics.

\footnotetext{
${ }^{1}$ Water year (WY) is defined as a 12-month period beginning October 1 and ending September 30 . The water year is designated by the calendar year in which it ends.
}

\section{Computer Requirements and Installation Instructions}

An active internet connection is required to download and install DRB-SET, and to use the map selection interface. Microsoft Excel ${ }^{\circledR}$ 97-2010 (or later), Microsoft.NET Framework 4.0 (x86 and x64), and Windows Installer 3.1 are required on the machine running DRB-SET. To install DRBSET, download the setup file from: http://paapps.er.usgs.gov/ apps/drb-set/ or http://dx.doi.org/10.3133/ofr20151192. Install DRB-SET by double clicking on the downloaded "setup. exe". Administrative privileges are not typically required to install/uninstall this application, unless the .net framework is not already installed. After launching setup.exe, the program checks for prerequisites and will notify you of any problems or missing software. After successful installation, the program will be in your start menu in a folder named "USGS PA WSC," and a shortcut will be created on your desktop. The associated report by Stuckey (2016) documenting the methodology used in DRB-SET can be downloaded from the USGS Publications Warehouse.

\section{Entering Input Data for DRB-SET}

DRB-SET requires basin characteristics for the ungaged stream location to be entered before computing daily mean streamflow. The opening screen of DRB-SET displays the DRB StreamStats application (fig. 1), in which users can zoom to an ungaged stream location within the Delaware River Basin, delineate a basin, and obtain basin characteristics. Users must zoom to a scale of 1:24,000 or larger before the delineation icon is available for use (black circle with cross). Click on the delineation icon and click on the point on the stream to delineate the basin and compute basin characteristics. Do not close the StreamStats delineation box. The computed basin characteristics are automatically entered into DRB-SET Basin Characteristics table under tab 2 (fig. 2). More information on StreamStats, including instructions for 
use, can be found at http://water.usgs.gov/osw/streamstats/ or Ries and others (2008).

Users can also go directly to tab 2 and manually enter the basin characteristics or use the StreamStats webservice. To use the StreamStats webservice, an outlet latitude and longitude in decimal degrees must be entered. Then click on the box at the top titled "Import from StreamStats Web Service." The computed basin characteristics are automatically populated in DRB-SET when utilizing this option. The delineated basin and computed basin characteristics can be downloaded as an Arc GIS geodatabase (version 10 or later) from tab 2 Basin Characteristics by clicking on the Download Basin GDB button.

The following basin characteristics are required to compute daily mean streamflow: latitude at the outlet, drainage area, mean annual precipitation, mean winter precipitation, saturated hydraulic conductivity, percentages of poorly drained soil and sand in soil, $\mathrm{x}$-location in decimal degrees at the center of the basin, and y-location in decimal degrees at the center of the basin. More information about these basin characteristics, including data sources, can be found in Stuckey (2016). The range of values for each basin characteristic used to develop the regression equations is shown in the table under tab 2. A warning message will appear if the basin characteristic value entered is outside this range, indicating the resulting flow-duration estimates determined from regression equations may not be valid. When determining the basin characteristics outside of StreamStats, it is important to use the same data source as was used to develop the regression equations for determination of the basin characteristics to maintain consistent accuracy in the regression estimates.

Text describing the ungaged watershed can be entered by clicking in the box Ungaged Site Description and entering text. This text will appear in the report file discussed in the next section "Running DRB-SET." To clear entered basin characteristics from the Basin Characteristics table under tab 2, click on the Clear Form button at the top of the page.

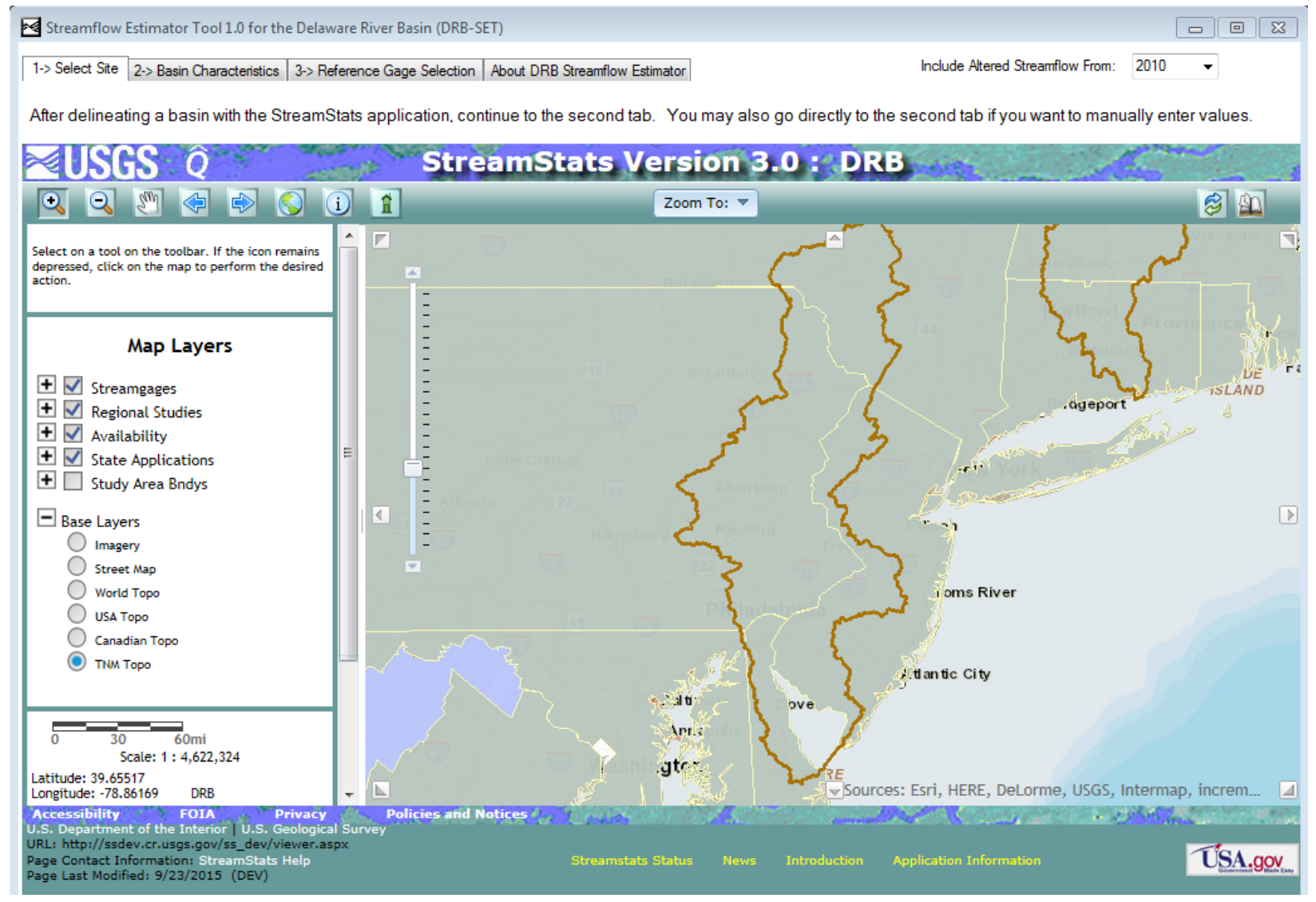

Figure 1. The opening screen of DRB-SET. 


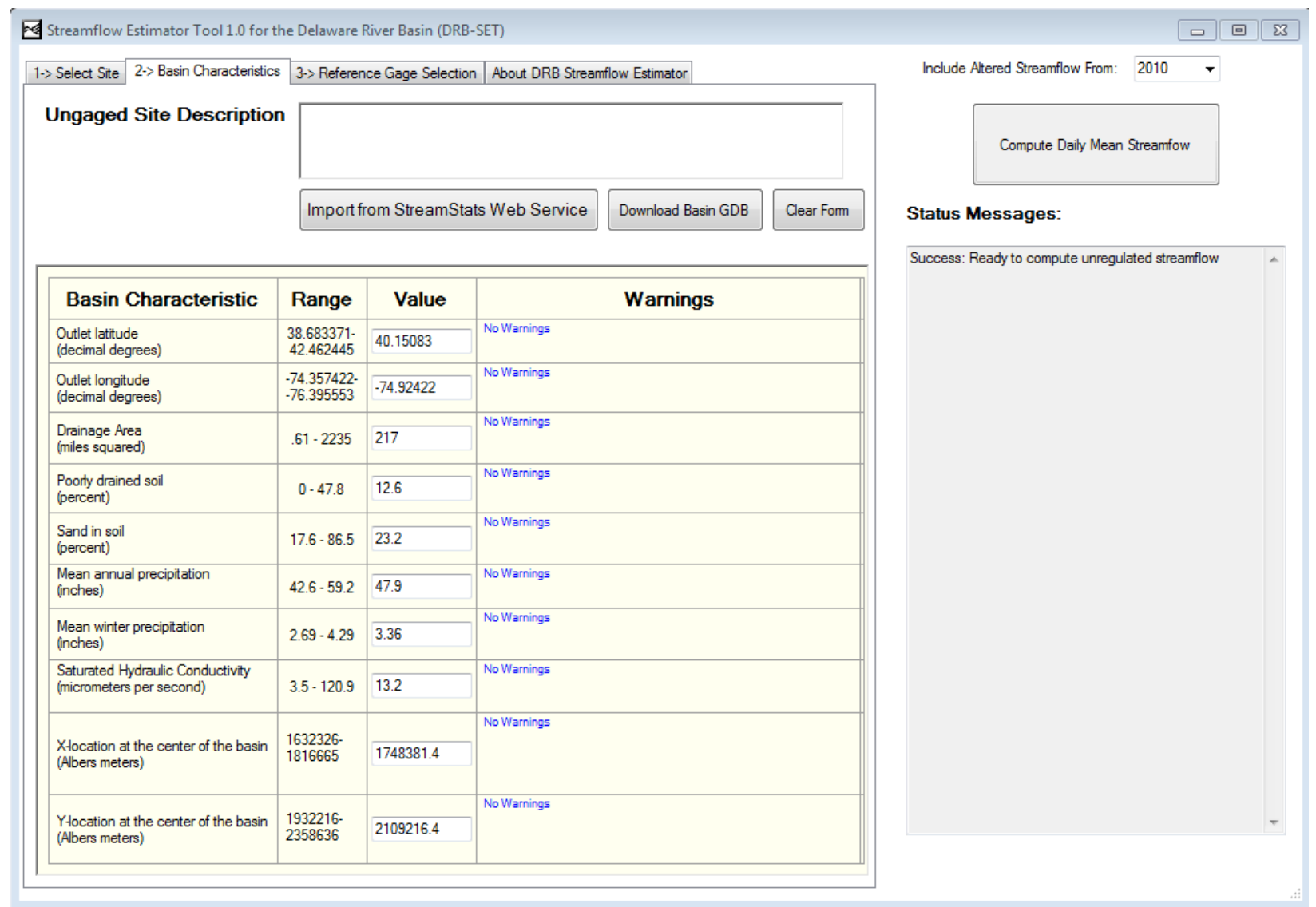

Figure 2. Basin Characteristics table in DRB-SET.

\section{Running DRB-SET}

After basin characteristics have been entered in the Basin Characteristics table under tab 2, the reference streamgage selection method can be selected and daily mean streamflow can be computed. By default, DRB-SET uses map correlation to select an appropriate reference streamgage. If a different method is preferred, the reference streamgage selection method can be changed under tab 3 (fig. 3). To manually select the reference streamgage, uncheck the Use Map Correlation box and scroll down the list of streamgages to choose a reference streamgage. To use the closest streamgage to the ungaged stream location, click on the Use Closest Gage box.

Under tabs 1-3, at the top right corner, the year from which the water use has been compiled can be selected. Water use data include withdrawals and return flows within the selected subbasin. Currently (2015), only water use data from 2010 are available in StreamStats and DRB-SET, but the functionality exists to add other data sets in the future. Informational text can be found under the About DRB Streamflow Estimator tab at the top of the tool.

After basin characteristics have been entered for the ungaged stream location and any changes have been made to the reference streamgage selection method, click on the Compute Daily Mean Streamflow button to compute baseline and altered daily flows. This button is found on either tab 2 Basin Characteristics or tab 3 Reference Gage Selection. The user will have to agree to the disclaimer that appears before continuing (fig. 4). The computation of daily flows will take a few minutes, depending on the computing capacity of your computer. A status bar indicates progress. When computations are completed, a window will open (may be behind other open screens) asking the user to save the resulting Microsoft Excel ${ }^{\circledR}$ file. Text in the Status Messages box in DRB-SET will alert users that the file is ready to be saved. This Microsoft Excel ${ }^{\circledR}$ file is the output from the tool. After saving the file, close the file before attempting to run DRB-SET for another location. DRB-SET may not function properly when this file is open.

The output Microsoft Excel ${ }^{\circledR}$ file contains worksheets titled BasinCharacteristics, ReferenceGageSelection, ContinuousFlowDuration, ContinuousDailyFlow, Report, and WaterUse. The BasinCharacteristics worksheet is a copy of the Basin Characteristics table from tab 2 in DRB-SET. The ReferenceGageSelection worksheet lists information about the reference streamgage selected and four other reference 


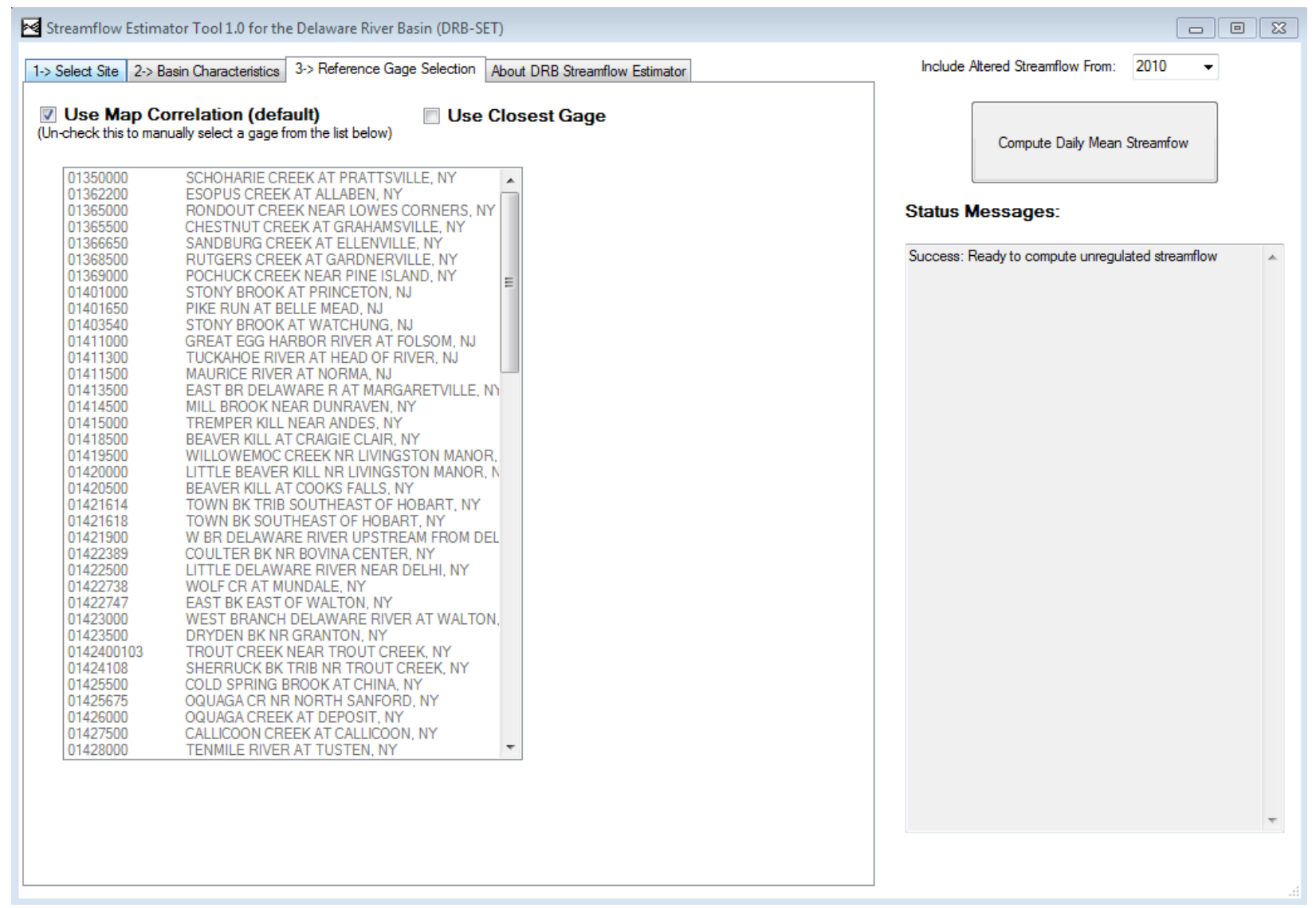

Figure 3. Reference Gage Selection tab in DRB-SET.

NOTICE
This software has been approved for release by the U.S. Geological Survey (USGS).
Although the software has been subjected to rigorous review, the USGS reserves
the right to update the software as needed pursuant to further analysis and
review. No warranty, expressed or implied, is made by the USGS or the U.S.
the fact of release constitute any such warranty. Furthermore, the software is
released on condition that neither the USGS nor the U.S. Government shall be held
liable for any damages resulting from its authorized or unauthorized use.
Do you agree to these terms?

Figure 4. Disclaimer from DRB-SET. 
streamgages with the highest correlations (Spearman's rho) to the ungaged stream location. The distances between the ungaged stream location and reference streamgages are listed in the table and can be used to evaluate the appropriateness of the selected streamgage. If the Use Closest Gage was selected in order to choose the reference streamgage, the five closest streamgages will be listed. The exceedance probabilities for the reference streamgage and ungaged stream location will be listed in the ContinuousFlowDuration worksheet. The daily mean streamflow for the reference streamgage and the estimated streamflow (both baseline and altered) for the ungaged stream location will be listed in the ContinuousDailyFlow worksheet.

The Report worksheet (fig. 5) lists the basin characteristics for the reference streamgage and ungaged stream location and the mean and median streamflow for the period 10/1/1959-09/30/2010 (water years 1960-2010). The Report worksheet plots the flow duration curve and hydrograph for the ungaged location. To save the estimated baseline and altered daily flows and dates for the ungaged stream location as a text file, click on the Export Daily Values button on the Report worksheet. Macros need to be enabled to use this feature. To enable macros, click on Enable Content from the message bar or under File, Info, Security Warning, Enable Content, select Enable All Content.

The WaterUse worksheet (fig. 6) lists the water use (both withdrawal and returns) in the ungaged basin. Return flows are listed annually and by month. Withdrawals are listed annually, monthly, and by water-use categories. Withdrawal categories include water supply, self-supplied domestic, industrial, irrigation, livestock, mining, power/ hydroelectric, remediation, sewage treatment, thermoelectric, aquaculture, and commercial. More information about the categories and water use compilation can be found in Hutson and others (in press). The mean and median altered streamflow at the ungaged stream location for the period from 10/1/1959-09/30/2010 (water years 1960-2010) are listed, and plots of the flow duration curve and hydrograph, both baseline and altered, for the ungaged stream location are shown. To save the estimated altered daily flows and dates for the ungaged stream location as a text file, click on the Export Daily Values button on the Report worksheet. Macros need to be enabled to use this feature. To enable macros, click on Enable Content from the message bar or under File, Info, Security Warning, Enable Content, select Enable All Content.

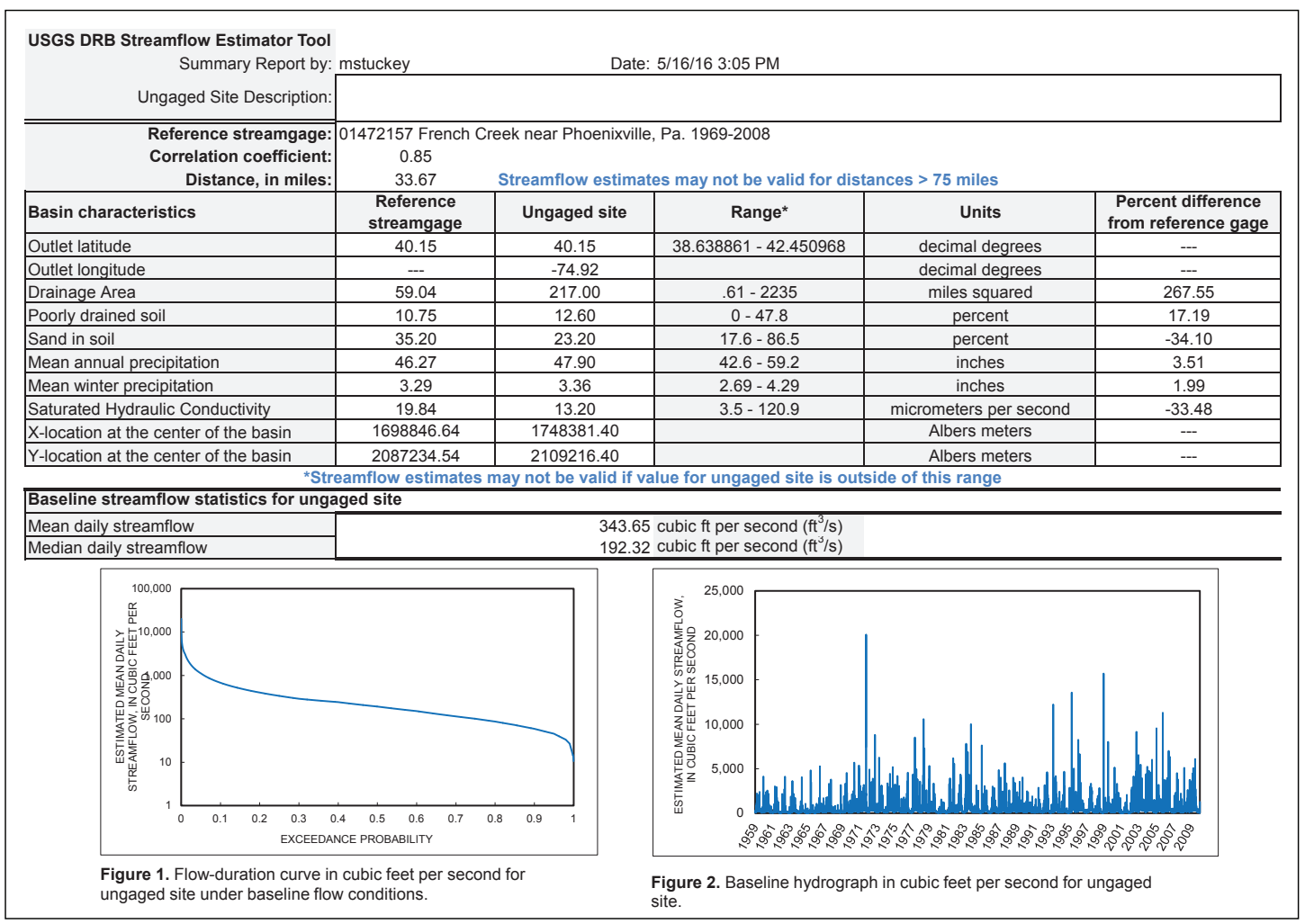

Figure 5. Report worksheet from DRB-SET. 


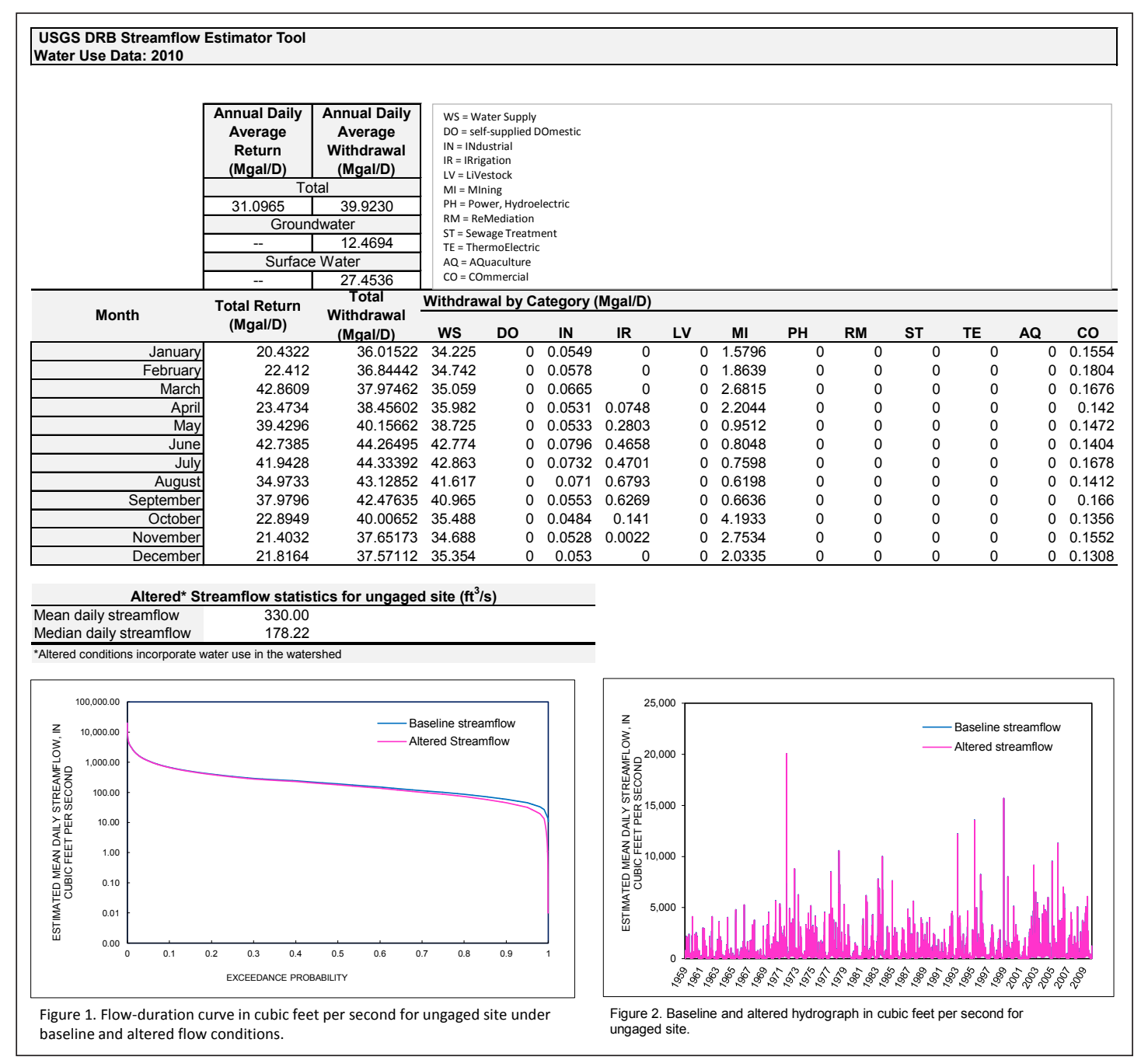

Figure 6. WaterUse worksheet from DRB-SET.

\section{References Cited}

Archfield, S.A., Vogel, R.M., Steeves, P.A., Brandt, S.L., Weiskel, P.K., and Garabedian, S.P., 2010, The Massachusetts Sustainable-Yield Estimator: A decision-support tool to assess water availability at ungaged stream locations in Massachusetts: U.S. Geological Survey Scientific Investigations Report 2009-5227, 41 p., plus CD-ROM.

Fennessey, N.M., 1994, A hydro-climatological model of daily streamflow for the northeast United States: Medford, Mass., Tufts University, Ph.D. dissertation [variously paged].

Hutson, S.S., Linsey, K.S., Ludlow, R.A., Reyes, Betzaida, and Shourds, J.L., in press, Estimated use of water in the Delaware River Basin in Delaware, New Jersey, New York, Pennsylvania, 2010: U.S. Geological Survey Scientific Investigations Report 2015-5142.
Ries, K.G., III, Guthrie, J.G., Rea, A.H., Steeves, P.A., and Stewart, D.W., 2008, StreamStats: A Water Resources Web Application: U.S. Geological Survey Fact Sheet 2008-3067, 4 p., http://pubs.usgs.gov/fs/2008/3067/.

Stuckey, M.H., 2016, Estimation of baseline daily mean streamflows for ungaged stream locations in the Delaware River Basin, water years 1960-2010: U.S. Geological Survey Scientific Investigations Report 2015-5157, 42 p., http://dx.doi.org/10.3133/sir20155157.

Stuckey, M.H., Koerkle, E.H., and Ulrich, J.E., 2014, Estimation of baseline daily mean streamflows for ungaged locations on Pennsylvania streams, water years 1960-2008 (ver 1.1, August 2014): U.S. Geological Survey Scientific Investigations Report 2012-5142, 61 p., http://pubs.usgs. gov/sir/2012/5142. 
Publishing support provided by the

U.S. Geological Survey Science Publishing Network,

West Trenton Publishing Service Center

For more information concerning the research in this report, contact:

Director, Pennsylvania Water Science Center

U.S. Geological Survey

215 Limekiln Road

New Cumberland, PA 17070

http://pa.water.usgs.gov/ 


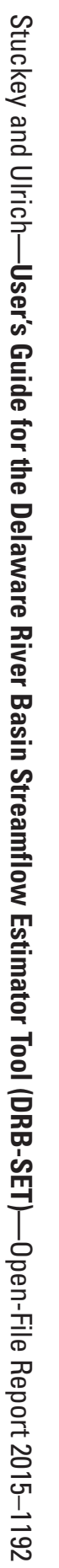

